\title{
Study on Q245 Steel fatigue crack growth behaviors at high temperature
}

Haibo Wang ${ }^{1,2}$, Dongpo Wang ${ }^{1}$, Fangjie Cheng ${ }^{1}$, Caiyan Deng ${ }^{1}$, Yunlong Wu ${ }^{1}$

${ }^{1}$ School of Materials Science and Engineering, Tianjin University, China. Weijin Rd, 92, Nankai, Tianjin 300072, China. Email:w.haib@qq.com,chfj@tju.edu.cn

${ }^{2}$ Tianjin Special Equipment Inspection Institute, China. Hangtian Street, Nankai, Tianjin 300192, China. *Corresponding Author: Associate professor Fangjie Cheng

Q245 steel was once widely used in the pressure vessel industry.At present, the high temperature fatigue performance of Q245 steel was tested and analyzed. According to the relevant standards, the pre-crack specimens were tested at $25^{\circ} \mathrm{C}$ and $400{ }^{\circ} \mathrm{C}$ respectively. The a-N curves, the $d a / d N-\Delta K$ curves and the Paris formula of Q245 steelat both room temperature $\left(25^{\circ} \mathrm{C}\right)$ and high temperature $\left(400^{\circ} \mathrm{C}\right)$ were obtained. Finally, the high temperature fatigue fracture analysis was done. The fatigue crack growth occurredalong the grain at high temperature. A large number of acicular oxideappearin the fracture surface and the fatigue striations could notbe observed at high temperature.

Keywords: High temperature; Fatigue crack;Fatigue crack growth threshold

\section{Acknowledgments}

The financial support by the science and technology project of AQSIQ(No.2013QK090) is also acknowledged.

\section{References}

[1] GONG XUE, XIE YUJUN. (2011). Stress Analysis of the Diaphragm Seal Plate of Diaphragm Heat Exchangers. J .Contemporary Chemical Industry, 19120-122

[2] HAO XU. (1988). Fatigue strength higher education press, Beijing, 284-290

[3] Steel plates for boiler and pressure vessel, S.The State Standard of the People's Republic of China, GB713-2008.

[4] ASTM committee E-24, Proposed ASTM test method for measure-mend of fatigue crack growth rates, in Fatigue Crack Growth Measurement and Data Analysis. ASTM STP 738-1981.

[5] SCHLITZ, W. (1996). A history of fatigue,J. Engineering Fracture Mechanic, 54(2) 263-300.

[6] VASUDEVAN, A. K., SADANANDA, K., LOUAT, N., (1994). A review of crack closure fatigue crack threshold and related phenomena, J. Materials Science and Engineering A, 188, 1-22.

[7] SADANANDA, K., VASUDEVAN, A. K., (2004). Crack tip driving forces and crack growth representation under fatigue ,J. International Journal of Fatigue, 26, 39-47.

[8] DENG ZENGJIE, ZHOU JINGEN, (1995). Fracture and fatigue of engineering materiál, CHINA MACHINE PRESS, Beijing,(1995)136-137

[9] Standard test method for fatigue crack growth rates of metallic materials, The State Standard of the People's Republic of China, GB 6398:2000.

[10] Metallic materials-Fatigue testing-Statistical planning and analysis of data, S.The State Standard of the People's Republic of China, GB 24176:2009.

[11] WANG Z X, SHI HAI, LU,J. (2008). Size effects on the ductile/brittle fracture properties of the pressure vessel steel 20g,J. Theoretical and Applied Fracture Mechanics. 50(2) 124-131.

[12] Metallic materials-Tensile testing at elevated temperature, The State Standard of the People's Republic of China, GB 4338:2006.

[13] Metallic materials -- Fatigue testing -- Statistical planning and analysis of data, S. ISO 12107:2012

[14] SCHIJVE, J. (2003). Fatigue of structures and materials in the 20th century and thestate of the art, J.International Journal of Fatigue, 25, 679-702. 